\title{
Biological control of mustard aphid, Lipaphis erysimi (Kaltenbach, 1843) through seven-spotted ladybird beetle, Coccinella septempunctata (Linnaeus, 1758) under laboratory conditions
}

\author{
Hakim Ali Sahito ${ }^{1,2^{*}}$, Rukhsana Solangi ${ }^{1}$, Tasneem Kousar ${ }^{1}$, Zafar \\ Hussain Shah ${ }^{1}$, Wali Muhammad Mangrio ${ }^{1}$ and Muhammad Mithal \\ Rind $^{1}$
}

1. Department of Zoology, Faculty of Natural Sciences, Shah Abdul Latif University, Khairpur Mir's, Sindh-

Pakistan

2. Date Palm Research Institute (DPRI), Shah Abdul Latif University, Khairpur Mir's, Sindh-Pakistan

*Corresponding author's email: hakim.sahito@salu.edu.pk

Citation

Hakim Ali Sahito, Rukhsana Solangi, Tasneem Kousar, Zafar Hussain Shah, Wali Muhammad Mangrio and Muhammad Mithal Rind. Biological control of mustard aphid, Lipaphis erysimi (Kaltenbach, 1843) through sevenspotted ladybird beetle, Coccinella septempunctata (Linnaeus, 1758) under laboratory conditions. Pure and Applied Biology. Vol. 8, Issue 2, pp1707-1717. http://dx.doi.org/10.19045/bspab.2019.80114

\begin{tabular}{llll}
\hline \hline Received: 27/03/2019 & Revised: 29/03/2019 & Accepted: 27/06/2019 & Online First: 29/06/2019
\end{tabular}

\section{Abstract}

The research study was conducted at the Entomology Laboratory, Department of Zoology, SALU, Khairpur during, 2017-18. Among biological parameters such as; fecundity, fertility, and egg hatching \% of a predator, seven-spotted ladybird beetle were 143, 165 and 86, respectively. Whereas; the results of the biology of seven-spotted ladybird beetle show that the first larval stage took up (4.08) days to develop into a second stage that took up (5.32) days, the third stage (6.80) days and the fourth stage (8.00) days to convert into pupae (6.04) days. The overall female days were observed up to (43.76) and the male (39.36). After hatching, the $1^{\text {st }}$ larval stage consumed up to (2) aphids whereas; the $2^{\text {nd }}$ stage (19), the $3^{\text {rd }}$ larval stage (34) with the $4^{\text {th }}$ stage (48) per day, later on, these larvae were converted into pupal stage thus, the adult stage consumed (40) aphids at per day. The ANOVA showed considerable differences in feeding efficiency of Seven-spotted ladybird beetle on aphids under laboratory conditions at $(\mathrm{P}<0.05)$. It is concluded; the ladybird beetle, $C$. septempunctata is well known as a good biological control agent because of predation in nature that has a short life cycle which is also a good character. Thus, the abovementioned species can be fruitfully used to minimize the sucking insect pests under mustard crop.

Keywords: Biology; Feeding behavior; Predator; Sucking pest

\section{Introduction}

Aphid, L. erysimi infests family; Cruciferae; various vegetables including mustard and oilseed crops, like; B. alba, B. campestris, $B$. napus, B. juncea and others; cruciferous beets, Beta vulgaris (Linnaeus); potato, Solanum tuberosum, (Linnaeus); tomato, Lycopersicon esculentum (Mill.); tobacco, Nicotiana tabacum (L.); a beneficial plant, Brigeron canadensis (L.); weeds, such as; 
Gynondropis pentaphylla (D.C.); Withania somnifera and Ageratum conyzoides (L.) [1]. Mustard L. erysimi (Kalt.) is a major pest of brassica crops. Which attacks numerous economically essential crops, more importantly, Cruciferae family. It is also serious in USA, Pakistan, India and many other countries of the globe. This pest (nymph and adult) causes damage to mustard plants from the initial cultivation to harvesting stage [2], suck the cell sap from leaves, stem, and inflorescence [3] resulting in the stunted growth of the plant, withering flowers and pod formation is hindered. Plants may be destroyed quickly by aphid as compare to other larger insects. Sometimes people face complete loss of the mustard crop by the high incidence of the pest [4].

It creates a severe infestation in the agriculture world. In nature mostly nourishment of aphids is on one or two varieties of plants, monophagous and nourishment of a few aphids is on different plant varieties, polyphagous such as aphid of Gossypium, A. gossypii (Glover) and aphid of the green peach, M. persicae (Sulzer) [5]. There are different names of aphids like black flies, greenflies, plant lice or tiny sapsucking insects. Aphids contain soft bodies and typical colors like dark brown, pink, green, white or nearly dull, with six legs. Aphids also contain a cauda; tail-like projection over their posterior space. They contain a pair of compound eyes which consisted of 3 centered points known as triommatidia [6]. Brassica campestris, mustard crop belongs to family Brassicaceae; is commonly called sarson, mostly cultivated varieties are, Brassica campestris, Brassica napus, E. Sativa and Brassica juncea. Generally, B. campestris and $B$. napus refer to rapeseed while, $B$. juncea, $B$. sativa, $B$. alba and $B$. carinata refer to mustard. The oil of the mustard seed is utilized for cooking purpose and preparation of soap, ointment while; the area on which mustard crop is grown in $81 \%$ of the total area [7]. The green leaves of rapeseed-mustard widely used for human diet as well as fodder in animal nutrient and their seeds contain oil 46-48\%, protein 43.6\% [8]. There is a most important role of mustard in import exchange, the utilization of oil in Pakistan increased from 0.3 to 1.95 million tons [9]. Pakistan costs a huge amount of foreign exchange on imports of edible oil from other countries due to its insufficient production, which is constantly the second largest import bill after petroleum and includes in the only largest expenses of import on foodstuff items. During the drought period of Pakistan in 2009-2010, import cost of edible oil of 1.246 million tons about 77.78 billion [10]. During cropping; 1999-2000, mustard and rapeseed crops were cultivated on 321.3 hectares with the yield of 289.5 tons in Pakistan. Pakistan consumed 19 lac tons of mustard edible oil and produced 10 lac tons so 9 lac tons were imported. In Sindh, the production of oilseed crop was 82.2 tons and the cultivation was made on 98.1 hectares [11]. The mustard crop was mostly grown in Pakistan during Rabi season. For sucking pests, the mustard crop was the most favorable and its 6 varieties mostly attacked in Sindh, which could be controlled through biological control [12]. Due to various biotic and abiotic factors, this crop also suffers heavy loss in yield [13], among these biotic components; the insect pests most damage the mustard yield.

Among coleopterans, Coccinellidae is a renowned and diversified family worldwide which contains about 6 thousand species of beetles [14]. Predaceous coccinellid beetles are rapacious feeders of insects like aphids, jassids, whiteflies, psyllids, mealybugs, mites, scale insects and also on eggs miniature grubs of different insects and also play an important role in forest and agroecosystems as the grubs and adults of the 
majority of the beetles are predacious on large numbers of plant-eaters insect pests [15]. These beetles are considered as beneficial insects, due to their predatory nature and as competent natural control agents against various insect pests [16], on which its larvae and adult feed energetically. Natural control of aphids is the best alternative for very poisonous and hazardous pesticides which are commonly utilized for controlling plant pests [17].

The seven-spotted ladybird, Coccinella septempunctata Lin. is a key predator of many aphid species; larvae of the cotton leafworm, eggs of Jassids, eggs and small nymphs of mealybugs, [18, 19]. In both larval and adult stage, these ladybird beetles are vigorous and have an extensive range of prey such as aphids and scale insects; the most destructive group of insects. These are the most important of all predators [20]. The adults and early stages are often encountered in large numbers of the plants infested with aphids. They eat these injurious pests and often play a certain role in bringing them under control. It preys on eggs, larvae, and adults of different species of insects and most importantly as a predator on aphids [21]. Adults of $C$. septempunctata can eat up to100 aphids per day [22, 23]. The ladybug kills its prey completely and then devours it [24]. During the current research study, this natural enemy, Seven-spotted ladybird beetle (Coccinella septempunctata) is the safest biological controlling agent of mustard aphid. Finally, the results were shared amongst the researchers, farmers growing mustard at District Khairpur Mir's.

\section{Material and methods}

Feeding efficacy of Seven Spotted ladybird beetle, $C$. septempunctata under laboratory conditions

The larvae of the first, second, third and fourth stage of seven spotted ladybird beetle were collected from field conditions and were carried to Entomology laboratory;
Department of Zoology, Shah Abdul Latif University, Khairpur, were kept in jars containing aphids to maintain the mass culture under laboratory conditions. For egg laying purpose in the inner surface of each jar, a blotting paper was spread out. For the hatching ability; females laid in eggs were counted and shifted to separate Petri dishes by using the soft camel hair brush. Finally, the observation of fertility and fecundity were done. The fresh leaves of mustard were provided daily as the food of pest. On daily basis aphid consumption was documented by counting unconsumed aphids, which were kept in Petri dishes separately and continued till the next developmental stage of larva as well as the counting of dead aphids in each Petri dish was also recorded as eaten by a natural enemy, while the wounded / sluggish larvae were replaced and maintained. The replication of the experiment was done 5 times in each case under vitro conditions. The hygrometer was used for measuring temperature and relative humidity under laboratory conditions. While at the bottom of the each Petri dish in which experiment was carried out a moistened Watsman $^{\circledR}$ filter paper was kept to keep away from drought and for managing adequate humidity. After hatching of eggs in their initial stages 50 number of counted aphids were provided as food source to extend its lifespan up to the adult stage and pest density of aphids either nymphs or adults, consumed by different stages of predators such as $1^{\text {st }}, 2^{\text {nd }}, 3^{\text {rd }}, 4^{\text {th, }}$ and adults, were observed under laboratory conditions. Consequently feeding efficacy was observed accordingly.

\section{Statistical analysis}

The statistical analysis of variance (ANOVA) and the least significant differences (LSD) of the pest population was recorded. In the end, the correlation of pest with a predator was also calculated. The predation and development at various stages 
of life of seven-spotted ladybird beetle under laboratory conditions were analyzed in comparison to pests/aphids, thus, the statistical data was described, ANOVA was done and the average values were compared using the LSD test $(\mathrm{P} \leq 0.05)$ by using Statistics (8.1) computer software, student package, USA.

\section{Results}

Fecundity, fertility, and egg hatching \% under laboratory conditions

The each contained a single pair of adult ladybird beetle in different five (5) jars were taken for a period of 7 days for copulation period to lay their eggs and aphids were also given in the jars as their nutrition. It was found that eggs were laid in cluster form mostly on the undersurface of leaves as well as in the bottom of jars and sides. The shapes of eggs when freshly; laid in were appeared an oval or cigar-shaped and the color was deep yellow shining, which becomes light black at reaching near to hatching. Then eggs were separated from jars and were placed in Petri dishes separately; in total 6 replications each containing 30 number of eggs. For counting the eggs observations were made twice a day at morning and evening during the incubation period. The color of eggs was changed from yellow to black after about 6 to 8 days, after hatching of larvae from eggs the fertility was found about 165. Then freshly hatched larvae were separated to know about the period of all four instars. Ecdysis of developed larvae was also observed twice a day and fecundity of eggs was recorded 143 approximately while hatching percentage of eggs was 86 and the period of laying of eggs was 8 days averagely. Freshly formed pupae were separated and kept in Petri dishes until the emergence of adult and data was collected two times a day at the morning time and evening time. Then freshly emerged male and female adults were kept individually in separate Petri dishes and provided an adequate number of aphids as food source regularly and data was collected on the longevity of adult.

The ANOVA determined the major differences $(\mathrm{DF}=4,3 ; \mathrm{F}=2.95 ; \mathrm{P}=0.06)$ amongst the weeks of data collection of fecundity, fertility, and egg hatching \% under laboratory conditions, LSD; AllPairwise Comparisons Test shows the Homogeneous groups which were divided into different groups at $(\mathrm{P}<0.05)$. Whereas; the (Table 1) shows the overall mean of eggs fertility was observed (164.64) of predators. The mean of eggs fecundity was observed (143.32). The overall eggs were hatched $86 \%$ from eggs within the mean of 8.32 days with their overall mean from eggs fertility to eggs laying days were (100.48), respectively.

Table 1. Fecundity, fertility and egg hatching percentage under laboratory conditions

\begin{tabular}{|c|c|c|c|c|c|}
\hline Trt. & Eggs fertility & Eggs fecundity & Egg hatched \% & Egg days & Mean \pm SD \\
\hline $\mathbf{T}_{\mathbf{1}}$ & $194.00 \pm 24.21$ & $151.60 \pm 19.64$ & $75.67 \pm 7.31$ & $8.00 \pm 0.63$ & $107.32 \pm 12.95^{\mathrm{abc}}$ \\
\hline $\mathbf{T}_{\mathbf{2}}$ & $117.20 \pm 16.34$ & $100.60 \pm 18.27$ & $84.79 \pm 6.44$ & $7.60 \pm 0.68$ & $77.55 \pm 10.43^{\mathrm{c}}$ \\
\hline $\mathbf{T}_{\mathbf{3}}$ & $185.40 \pm 32.45$ & $166.40 \pm 34.18$ & $87.36 \pm 4.73$ & $9.20 \pm 0.58$ & $112.09 \pm 17.99^{\mathrm{ab}}$ \\
\hline $\mathbf{T}_{\mathbf{4}}$ & $127.60 \pm 29.12$ & $116.20 \pm 29.94$ & $88.81 \pm 3.64$ & $7.20 \pm 0.58$ & $84.95 \pm 15.82^{\mathrm{bc}}$ \\
\hline $\mathbf{T}_{\mathbf{5}}$ & $199.00 \pm 28.64$ & $181.80 \pm 24.95$ & $91.57 \pm 2.12$ & $9.60 \pm 0.24$ & $120.49 \pm 13.82^{\mathrm{a}}$ \\
\hline Mean \pm SD & $164.64 \pm 26.15$ & $143.32 \pm 25.40$ & $85.64 \pm 4.85$ & $8.32 \pm 0.54$ & $100.48 \pm 14.20^{\mathrm{ab}}$ \\
\hline
\end{tabular}




\section{Biology of seven spotted ladybird beetle under laboratory conditions}

After hatching within a few minutes, the blackish larvae of seven spotted ladybird beetle started eating on aphids and after full development, the larvae contain orange pigments on its outer body surface then larva went through 4 stages of instars to become a pupa. During this larva of $1^{\text {st }}$ instar took averagely of four days, $2^{\text {nd }}$ instar took five days, $3^{\text {rd }}$ instar took seven days and $4^{\text {th }}$ instar of larva took averagely of eight days to develop into a pupa. While the range of period of a pupa was 6 to 9 days and had " $v$ " shaped appearance. The survival time of adult male was 39 and of female 44 days. The younger stages of aphids were preferably eaten by the larva. The mature larva remained inactive for few hours to one day, then became pupa by attaching itself to the surface of Petri dish with the posterior portion of the abdomen. The shape of the adult beetle of mediumsized was spherical and semi-circular. The difference between female and male was found that females were larger in size as compared to males, posses on their $6^{\text {th }}$ segment of the abdomen a slit-like opening and also consumed higher number aphids as compared to males.

The ANOVA determined the major differences $(\mathrm{DF}=6,4 ; \mathrm{F}=141.07 ; \mathrm{P}=0.001)$ of the population of the life cycle from larvae to adult under laboratory conditions, LSD, All-Pairwise Comparisons Test shows the Homogeneous groups which are divided into different groups at $(\mathrm{P}<0.001)$. Whereas; the (Table 2) shows that the $1^{\text {st }}$ larval instar takes mean of (4.08) to develop into $2^{\text {nd }}$ larval instar. The $2^{\text {nd }}$ stage takes the mean of (5.32) days. The $3^{\text {rd }}$ larval instar takes mean of (6.80) days. The $4^{\text {th }}$ larval instar takes mean of (8.00) days to develop into pupae. The pupae take mean of (6.04) days. The mean (43.76) of overall female days was observed. The mean (39.36) of overall male days was observed. Their overall mean from the $1^{\text {st }}$ stage to adult was observed (16.19) days, respectively.

Table 2. Biology of seven spotted ladybird beetle under laboratory conditions

\begin{tabular}{|c|c|c|c|c|c|c|c|c|}
\hline \multirow{2}{*}{ Trt. } & \multicolumn{4}{|c|}{ Larval stages } & \multirow{2}{*}{ Pupae } & \multirow{2}{*}{$\begin{array}{c}\text { Overall } \\
\text { female } \\
\text { days }\end{array}$} & \multirow{2}{*}{$\begin{array}{c}\text { Overall } \\
\text { male days }\end{array}$} & \multirow{2}{*}{$\begin{array}{c}\text { Mean } \\
\pm \\
\text { SD } \\
\end{array}$} \\
\hline & $1^{\text {st }}$ & $2^{\text {nd }}$ & $3^{\text {rd }}$ & $4^{\text {th }}$ & & & & \\
\hline $\mathbf{T}_{1}$ & $3.80 \pm 0.37$ & $\begin{array}{c}4.20 \pm 0.5 \\
8\end{array}$ & $\begin{array}{c}5.80 \pm 0.5 \\
8\end{array}$ & $\begin{array}{c}6.00 \pm 0.7 \\
1\end{array}$ & $\begin{array}{c}5.20 \pm 0.8 \\
6\end{array}$ & $\begin{array}{c}33.80 \pm 2.5 \\
2\end{array}$ & $\begin{array}{c}31.40 \pm 2.2 \\
7\end{array}$ & $\begin{array}{c}12.89 \pm 1.13 \\
\mathrm{~b}\end{array}$ \\
\hline $\mathbf{T}_{2}$ & $5.00 \pm 0.71$ & $\begin{array}{c}6.20 \pm 0.7 \\
3 \\
\end{array}$ & $\begin{array}{c}8.20 \pm 0.7 \\
3 \\
\end{array}$ & $\begin{array}{c}9.20 \pm 0.8 \\
6 \\
\end{array}$ & $\begin{array}{c}6.40 \pm 0.9 \\
3 \\
\end{array}$ & $\begin{array}{c}54.20 \pm 1.8 \\
3 \\
\end{array}$ & $\begin{array}{c}50.60 \pm 2.2 \\
0\end{array}$ & $\begin{array}{c}19.97 \pm 1.14 \\
\mathrm{a}\end{array}$ \\
\hline $\mathbf{T}_{\mathbf{3}}$ & $3.80 \pm 0.37$ & $\begin{array}{c}5.80 \pm 0.6 \\
6 \\
\end{array}$ & $\begin{array}{c}7.00 \pm 1.1 \\
0 \\
\end{array}$ & $\begin{array}{c}8.00 \pm 0.7 \\
1 \\
\end{array}$ & $\begin{array}{c}5.40 \pm 0.7 \\
5 \\
\end{array}$ & $\begin{array}{c}46.60 \pm 2.9 \\
9 \\
\end{array}$ & $\begin{array}{c}38.00 \pm 2.4 \\
9 \\
\end{array}$ & $\begin{array}{c}16.37 \pm 1.30 \\
\mathrm{ab}\end{array}$ \\
\hline $\mathbf{T}_{4}$ & $3.60 \pm 0.40$ & $\begin{array}{c}5.20 \pm 0.5 \\
8 \\
\end{array}$ & $\begin{array}{c}6.20 \pm 0.5 \\
8 \\
\end{array}$ & $\begin{array}{c}8.40 \pm 1.0 \\
3 \\
\end{array}$ & $\begin{array}{c}7.60 \pm 0.8 \\
1 \\
\end{array}$ & $\begin{array}{c}41.20 \pm 3.0 \\
4\end{array}$ & $\begin{array}{c}37.00 \pm 2.1 \\
7 \\
\end{array}$ & $\begin{array}{c}15.60 \pm 1.23 \\
\mathrm{~b}\end{array}$ \\
\hline $\mathbf{T}_{5}$ & $4.20 \pm 0.37$ & $\begin{array}{c}5.20 \pm 0.9 \\
7\end{array}$ & $\begin{array}{c}6.80 \pm 1.1 \\
6 \\
\end{array}$ & $\begin{array}{c}8.40 \pm 1.0 \\
3\end{array}$ & $\begin{array}{c}5.60 \pm 0.8 \\
1\end{array}$ & $\begin{array}{c}43.00 \pm 3.3 \\
9\end{array}$ & $\begin{array}{c}39.80 \pm 2.8 \\
5\end{array}$ & $\underset{\mathrm{b}}{16.14 \pm 1.51}$ \\
\hline $\begin{array}{c}\text { Mea } \\
\mathbf{n} \pm \\
\text { SD } \\
\end{array}$ & $4.08 \pm 0.45$ & $\begin{array}{c}5.32 \pm 0.7 \\
1\end{array}$ & $\begin{array}{c}6.80 \pm 0.8 \\
3\end{array}$ & $\begin{array}{c}8.00 \pm 0.8 \\
7\end{array}$ & $\begin{array}{c}6.04 \pm 0.8 \\
3\end{array}$ & $\begin{array}{c}43.76 \pm 2.7 \\
5\end{array}$ & $\begin{array}{c}39.36 \pm 2.4 \\
0\end{array}$ & $\underset{\mathrm{b}}{16.19 \pm 1.26}$ \\
\hline
\end{tabular}

Feeding efficiency of Seven-spotted ladybird beetle, $C$. septempunctata on aphids under laboratory conditions
The $1^{\text {st }}, 2^{\text {nd }}, 3^{\text {rd }}$ and $4^{\text {th }}$ instars larval stages of seven-spotted ladybird beetle, $C$. septempunctata have consumed aphids significantly at $(\mathrm{P}<0.05)$. A maximum 
number of aphids was consumed by $4^{\text {th }}$ instar larval stage of seven-spotted ladybird beetle in comparison to $1^{\text {st }}, 2^{\text {nd }}$ and $3^{\text {rd }}$ because of the improvement in insect age and larger size. In laboratory conditions, seven-spotted ladybird beetle consumed more aphids in as comparison to field conditions because in laboratory conditions beetles have less area to move so those actively feed on aphids which is only their source of food while under field conditions, the beetles eat fewer aphids because those cover more distance and spent greater time in searching the aphid. During March to April under laboratory conditions on mustard aphid, L. erysimi, the first instar predator averagely consumed 2 aphids, second instar 19, third instar 34, fourth instar 48 and the adult consumed 40 aphids with the overall mean was 28 . It was shown in the observations that there is a clear difference in feeding behavior between larval stages of seven-spotted ladybird beetle. The $4^{\text {th }}$ instar larval stage consumed a maximum number of aphids (47.70 \pm 1.80$)$ per day followed by $3^{\text {rd }}$ larval instar (33.75 \pm 0.59$)$, second instar $(18.60 \pm 0.92)$ and first instar $(1.74 \pm 0.53)$ and the number of aphids consumed by an adult was $(39.63 \pm 1.14)$ per day. The larval stages of $3^{\text {rd }}$ and $4^{\text {th }}$ instar were rapacious eaters, the larval stage of $4^{\text {th }}$ instar significantly consumed a greater number of aphids per day. As revealed from the data that the consumption of aphids increased gradually from $1^{\text {st }}$ to $4^{\text {th }}$ instar it means feeding rate of the larva was directly proportional to the growth of larva.

The ANOVA determined the major differences $(\mathrm{DF}=4,6 ; \mathrm{F}=4.17 ; \mathrm{P}=0.05)$ of the population of feeding effectiveness of $C$. septempunctata, Seven-spotted ladybird beetle on aphids under laboratory conditions, LSD All-Pairwise Comparisons Test shows the Homogeneous groups which are divided into different groups at $(\mathrm{P}<0.05)$. Whereas; the (Table 3) shows that the $1^{\text {st }}$ larval instar eats mean of (2) aphids after hatching. The $2^{\text {nd }}$ stage takes the mean of (19) aphids per day. The $3^{\text {rd }}$ larval instar eats mean of (34) aphids per day. The $4^{\text {th }}$ larval instar eats mean of (48) days to develop into pupae. The adult eats a mean of 40 aphids per day. Their overall mean from the $1^{\text {st }}$ stage to adult was observed (28) aphids per days.

Table 3. Feeding efficiency of Seven-spotted ladybird, $C$. septempunctata beetle on aphids under laboratory conditions

\begin{tabular}{|c|c|c|c|c|c|c|}
\hline \multirow[b]{2}{*}{ Trt. } & \multicolumn{4}{|c|}{ Larval stages } & \multirow[b]{2}{*}{ Adult } & \multirow{2}{*}{$\begin{array}{c}\text { Mean } \\
\pm \\
\text { SD }\end{array}$} \\
\hline & $1^{\text {st }}$ & $2^{\text {nd }}$ & $3^{\text {rd }}$ & $4^{\text {th }}$ & & \\
\hline $\mathbf{T}_{1}$ & $1.73 \pm 0.77$ & $18.38 \pm 0.88$ & $33.39 \pm 0.75$ & $48.75 \pm 2.44$ & $36.89 \pm 1.25$ & $27.68 \pm 1.22^{\mathrm{a}}$ \\
\hline $\mathbf{T}_{2}$ & $1.62 \pm 0.47$ & $18.29 \pm 0.80$ & $35.81 \pm 0.57$ & $48.46 \pm 2.87$ & $37.40 \pm 1.25$ & $28.67 \pm 1.19^{a}$ \\
\hline $\mathbf{T}_{3}$ & $1.79 \pm 0.45$ & $18.21 \pm 1.10$ & $33.63 \pm 0.71$ & $47.14 \pm 1.05$ & $41.29 \pm 1.19$ & $28.39 \pm 0.90^{\mathrm{a}}$ \\
\hline $\mathbf{T}_{4}$ & $1.78 \pm 0.34$ & $18.75 \pm 0.94$ & $33.24 \pm 0.50$ & $48.11 \pm 1.87$ & $38.66 \pm 1.05$ & $28.31 \pm 0.94^{\mathrm{a}}$ \\
\hline $\mathbf{T}_{5}$ & $1.76 \pm 0.60$ & $19.38 \pm 0.90$ & $32.70 \pm 0.40$ & $46.04 \pm 0.79$ & $43.91 \pm 0.95$ & $28.68 \pm 0.73^{\mathrm{a}}$ \\
\hline $\begin{array}{c}\text { Mean } \pm \\
\text { SD }\end{array}$ & $1.74 \pm 0.53$ & $18.60 \pm 0.92$ & $33.75 \pm 0.59$ & $47.70 \pm 1.80$ & $39.63 \pm 1.14$ & $28.35 \pm 1.00^{\mathrm{a}}$ \\
\hline
\end{tabular}

\section{Regression analysis between pest and predator}

The result of the current experimental study indicates that the population of pest and predator is positively correlated $(\mathrm{y}=2.04577$; $\mathrm{x}=0.0636 ; \mathrm{p}=0.004)$ because the population of a predator, $C$. septempunctata was increased due to increase in the population of pest $L$. erysimi. Therefore, the significant and +ve correlation was recorded between 
the population of seven-spotted ladybird beetle, $C$. septempunctata and population of aphid, L. erysimi. It was observed that by increasing the available food (aphid), at the same time the population of $C$. septempunctata increased under field conditions.

\section{Discussion}

In the current experimental work under laboratory conditions, the eggs fecundity was observed up to (143.32) with the 4 times shedding of the larval stage occurs to become a pupa. For becoming an adult pupa took the overall mean of (6.04) days. The female longevity was observed up to (43.76) days with the male (39.36) days. Thus, [25] observed that during Females' lifespan, eggs fecundity (657.7), grub takes an average duration of (9.27) days to pass through four instars, average (6.52) days for the pupal period and longevity of female and male (25.50) days and (21.08), respectively. The greater tendency was also of the feeding of seven-spotted ladybird beetle on aphid over B. brassicae, A. gossypii, $M$. pisum, and A. craccivora [26] he found the beetle consumed $L$. erysimi in the majority among all of these, followed by $B$. brassicae and Aphis gossypii the least. Whereas; [27] experimented on the 4 species of aphids as food preference of seven-spotted ladybird beetle so beetle consumed the highest number of aphids of cabbage, $B$. brassicae followed by L. erysimi, A. craccivora, and $A$. gossypii. The adult of seven-spotted ladybird beetle, $C$. septempunctata consumed from a range of 58 to 90 mustard aphids on averagely 72.77 aphids per day under laboratory conditions [28].

Our results show that the $1^{\text {st }}$ to $4^{\text {th }}$ larval instar stages of $C$. septempunctata consumed overall mean of (1.74), (18.60), (33.75) and (47.70) nymphs of $L$. erysimi per day in the laboratory. An experiment was also performed in the laboratory for finding the predatory potential of seven-spotted ladybird beetle, on mustard aphid, L. erysimi (Kalt.) and [29] further reported that $1^{\text {st }}$ to $4^{\text {th }}$ larval stages instars of seven-spotted ladybird beetle consumed (22.78), (66.00), (172.50) and (333.11) L. erysimi nymphs per day, respectively. They also found per day feeding potential and found that the females consumed 140.68 aphids in comparison to male 119.80 aphids. The maximum consumption of aphids per day by the females of $C$. septempunctata in comparison of males, 151.18 to 179.33 (average 165.27) and 120.14 to 144.29 (average 132.32), respectively [30]. They also described that during a complete larval period, the four stages of larval instars of seven-spotted ladybird beetle consumed (22.86 to 24.56), (71.13 to 71.67$)$, (178.66 to 185.48$)$ and (333.44 to 338.70) aphids, respectively with an average consumption of (612.91 to 613.56) aphids. On the other hand, these findings are approximately in close relation with that the consumption of (399 - 425) individuals of $L$. erysimi by the grub of $C$. septempunctata in its lifespan.

In our results, 4 to 6 days was incubation period; an average of 24 days larval period. Average living period of adult females was 44 days by producing 600 eggs. The average consumption of aphids by an adult female was 190 per day and consumption of aphids by an adult male was 180 per day. Our results vary from [31] who find out that per day female and male $C$. septempunctata averagely consumed 126 and 112.40 aphids, respectively while grub and adult took (70 and 75) seconds, respectively in consuming a single aphid. The female in its entire lifespan laid 193-1053 eggs with an average of (617.2) eggs [32]. The hatching period of eggs was (3.8) and (8.2) days. According to our findings, the adult female in its entire lifespan laid 500 to 600 eggs and the hatching time of eggs was 6 - 8 days. The female of $C$. septempunctata during her life laid a maximum number of 562 eggs, 
averagely (395) eggs [33]. During FebruaryMarch different period of the larval stage of C. septempunctata in Bihar the minimum (10.0 -11.0), maximum (16.0-17.0) and average (13.0-14.0) days, respectively [34]. The range of the pupation percent remained between 87.5 to 91.35 percent. In February more adult longevity days were found than in March $(16.73,13.50)$ respectively. While; our findings during the months of MarchApril were different, the minimum days of the larval stage of $C$. septempunctata were recorded 3-5, maximum 4-7 and the average duration of the larval stage of $C$. septempunctata were 6 to 8 days. So averagely larva took 6-8 days to become a pupa and the longevity of adult were found more in March (44) days than in April (40) days. According to the [35] who observed the life history of seven-spotted ladybird beetle, $C$. septempunctata and described that (4.5) days was the incubation period, (8.9) days was the larval period and (42) days were adult females living period and production of eggs was (518).

Our observations were that the lifetime of male and female were 39 days and 44 days, respectively, whereas; the aphid consumption by the adult female of sevenspotted ladybird beetle was more than an adult male. While in our findings, larvae consumed a number of aphids than adults. Similar types of results were observed by [36-42] about the feeding capacity of $C$. septumpunctata, who have found out that generally more consumption of aphids by larvae than adults. One reason for consumption of a greater number of aphids by females than males is that the body size of female adult ladybird beetles is larger than male and second reason is that the female ladybird beetle for laying eggs has need of greater energy that's why these consumes more aphids as a source of food.

According to [43] adult of seven-spotted ladybird beetle consumed (95-104) aphids in
24 hours. While, averagely (284.60) aphids were devoured by a larva of seven-spotted ladybird beetle for becoming a pupa, although, adults consumed (95) aphids per day [32]. A single aphid consumed by a predator beetle within 2-5 minutes. According to our results, a grub of $C$. septempunctata for becoming a pupa consumed average (103.6/101.79) number of aphids and adults consumed averagely (38.56/39.63) aphids and [44] find out that $1^{\text {st }}$ to $4^{\text {th }}$ larvae instars of seven-spotted ladybird beetle devoured (21.8), (46.6), (111.2) and (189.1) aphids, respectively. He also found that within 24 hours adults of male and female seven-spotted ladybird beetles devoured (45.8 and 58.7) aphids respectively. The consumption of nymphs and adults of aphids; L. erysimi by the $1^{\text {st }}$, $2^{\text {nd }}, 3^{\text {rd }}$ and $4^{\text {th }}$ larvae instars of seven-spotted ladybird beetle devoured (22.78), (66.00), (172.50) and (333.11) respectively whereas; the total lifespan of larvae was 12 days [29] also reported that the lifespan of male $\mathrm{C}$. septempunctata ranged from 19-26 days and of a female was 22-32 days and these devoured averagely (22 and 26) aphids per day per adult, respectively. It is further concluded that according to our research study and observations revealed that the first, second, third and fourth instar of larvae of $C$. septempunctata devoured an average of (1.74), (18.60), (33.75) and (47.70) aphids that show the full control measure of biological control that should be adopted to get rid of from the most toxic insecticides used in our agro-ecosystem. The current study recommends; the more experimental study should be done on the mustard insect pests properly for the betterment in the production of mustard edible oil as less work has been reported from this region.

\section{Conclusion}

It was concluded that the mustard crop was found to be most vulnerable to the sucking insect pests from the beginning up to the 
harvesting especially; mustard aphids causing high-level damage which was reduced through its biological control agent that was confirmed under laboratory conditions. The biology of the predator was also observed that consumed the minimum days and maximum feeding efficacy to complete its life cycle that should be encouraged at the biological control insectaries level.

\section{Authors' contributions}

Conceived and designed the experiments: HA Sahito, Performed the experiments: R Solangi \& T Kousar, Analyzed the data: ZH Shah, WM Mangrio \& MM Rind, Contributed materials/ analysis/ tools: $\mathrm{ZH}$ Shah, WM Mangrio \& MM Rind, Wrote the paper: R Solangi, ZH Shah, WM Mangrio \& MM Rind.

\section{References}

1. Phadke KG \& Prasad SK (1983). Some basic aspects of aphid management in rapeseed-mustard crops. In Principles and concepts of integrated pest management, ICAR, New Delhi, pp181185.

2. Verma SN \& Singh OP (1987). Estimation of avoidable losses to mustard by the aphid, Lipaphis erysimi in Madhya Pradesh. Ind J of Plant Prot 15(1): 87-89.

3. Singh H, Gupta DS, Yadav TP \& Dhawan K (1980). Post harvest losses caused by aphid, L. erysimi (Kalt.) and painted bug, Bagrada cruiciferarum (Kirk) to mustard. Haryana Agri Uni Res J 10: 407-409.

4. Rohilla HR, Bhatanagar P \& Yadav PR (2004). Chemical control of mustard aphid with newer and conventional insecticides, Ind J of Entomol 66(1): 3032.

5. Nozato K (1993). Behavioural traits of Aphis gossypii Glover (Homoptera: Aphididae), in relation to its flight and reproduction and efforts of natural enemies on the survival of the aphid. Sci Bult Faculty of Agri Kochi Uni 37: 121129.

6. Piper R (2007). Pests: A Guide to the World's Most Maligned, Yet Misunderstood Creatures, pp 283.

7. Nazir S (1994). Oil seeds crops. Crop Production, National Book Foundation, Islamabad, pp 374-380.

8. Huxley AMG \& Levy M (1992). The New Royal Horticultural Society, Dictionary of Gardening. Volume IV. Mc Millan, London, pp 181-193.

9. Agricultural Statistics of Pakistan. (2005). Ministry of Food Agriculture and Live Stock (Economic Wing), Islamabad, pp 201-211.

10. MINFAL (2010). Pakistan economic survey (2009-10). Govt. of Pakistan, Finance Div. (Econ. Advisor's Wing) Islamabad, Pakistan.

11. Vekaria MV \& Patel GM (2000). Screening of promising Brassica and allied genotypes for resistance against mustard aphid, Lipaphis erysimi. Ind $J$ of Entomol 62(1): 37-42.

12. Sahito HA, Lanjar AG \& Mal B (2010). Studies on population dynamics of sucking insect pests of mustard crop (Brassica campestris). Pak J of Agri Eng and Vet Sci 26(1): 66-74.

13. Mahto RN \& Mahto JL (2007). Stability analysis for yield and its component in mustard, Brassica juncea (L.). $J$ of Oilseed Res 24(1): 180-182.

14. Akhavan E, Jafari R, Jafai R \& Afrogheh S (2013). Biodiversity and distribution of predaceous ladybird (Coleoptera: Coccinellidae). Inter Res $J$ of Appl Basic Sci 5: 705-709.

15. Hodek I \& Honek A (2009). Scale insects, mealybugs, whiteflies and psyllids (Hemiptera, Sternorrhyncha) as prey of ladybirds. Biol Cont 51: 232243. 
16. Ali JG \& Agrawal AA (2014). Asymmetry of plant-mediated interactions between specialist aphids and caterpillars on two milkweeds. Funct Ecol 28: 1404-1412.

17. Bellows TS (2001). Restoring population balance through natural enemy introductions. Biol Contr 21: 199-205.

18. Ibrahim MM (1948). The morphology and anatomy of Coccinella undecimpunctata aegyptiaca Reiche. Bull Soc ler Entom 32: 305-316.

19. Ibrahim MM (1955a). Studies on Coccinella undecimpunctata aegyptiaca Reiche. I. Preliminary notes and morphology of the early stages. Bull Soc Entom Egypt 39: 251-274.

20. Shepard BM (1998). Insects and their natural enemies associated with vegetables and soybean in Southeast Asia. Quality Printing Co. Orangeburg, South Carolina, U.S.A. pp 22-24.

21. Ibrahim MM (1955b). Studies on Coccinella undecimpunctata aegyptiaca Reiche. II. Biology and life-history. Bull Soc Entom Egypt 39: 395-423.

22. Mutti S (2006). RNA Knock down of a salivary Transcript Leading to Lethality in the Pea Aphid, Acyrthosiphon pisum. $J$ of Insect Sci 6(38): 1-7.

23. Arnett Jr Ross, Downie NM \& Jaques HE (1980). How to know the beetles. Wm. C Brown Company Publish, Dubuque, Iowa.

24. Waldbaur G (1998). The Birder's bug book. Harvard university press, Cambridge, Massachusetts.

25. Mishra SK (2003). Bio-Ecology and Management of Mustard Aphid, Lipaphis Erysimi (Kali.) On Mustard with Special Reference to Biocontrol Agents (Doctoral dissertation, Rajasthan Agricultural University; Bikaner.

26. Anand RK (1983). Predation by Coccinella septempunctata Linn. and
Menochilus sexmaculata Fab. on five species of aphids. Pranikee 4: 234-237.

27. Singh MP \& CS Devi. (1996). Food preference of Coccinella septempunctata (Linn.) on aphids insect environment. 2(1): 5-6.

28. Malik YP, Bhagwan, Deen, Singh SV \& Deen B (1998). Feeding propensity of different Coccinellids on mustard aphid, Lipaphis erysimi. Ind $J$ of Entomol 60(4): 414-415.

29. Singh D \& Singh H (1994). Predatory potentiality of immature stages of lacewing, Chrysopa sp. and syrphid, Episyrphus balteatus (Degears) over mustard aphid, L. erysimi (Kalt.). Crop Res Hisar 7(1): 116-119.

30. Gour IS \& Pareek BL (2003). Biology and predation potential of Coccinella septempunctata Linnaeus on mustard aphid, Lipaphis erysimi (Kalt.) in SemiArid region of Rajasthan. Annals of Biol Hissar 19(2): 225-229.

31. Okuno T (1961). Feeding tests and some field observation of three aphidophagous coccinellids. Publ in Entomol Lab Agri University Osaka 6: 149-152.

32. Singh R \& Malhotra RK (1979). Bionomics of $C$. septempunctata (Linn.). Ind $J$ of Entomol 41(3): 244-249.

33. Sharga VS (1948). Biological control some hemipterous insect pests of crops in India. Curri Sci 17: 302-303.

34. Singh VS, Yadav RP \& Singh R (1994). Post-embryonic development, survival rate and predation potential of $C$. septempunctata (Linn.) in relation to mustard aphid, L. erysimi (Kalt.). J of Entomol Res 18(1): 5-10.

35. Jagdish P, Prabhuraj S, Manjunatha A, BN \& Seetharam A (1996). Biology of Coccinella septempunctata Linn., $C$. transversalis Fab. (Coccinellidae: Coleoptera) and an unidentified species of hamerobiidae on Hysteroneura setaria Thomas (Aphididae: 
Homoptera). Mysore J of Agri Sci 30(1): 52-57.

36. Saxena HP, Sircar P \& Pkokela A (1970). Predation of Coccinella septempunctata and Ischiodan scutellaris Fab. on Aphis craccivora Koch. Ind J of Entomol 32(1): 105-106.

37. Verma KL \& Chowdhuri SN (1975). Predation of peach leaf curl aphid, Brachycaudus helichrysi (Kalt.) by $C$. septumpunctata Linneous. Ind $J$ of Entomol 37(3): 315-316.

38. Srivastava AS, Upadhyay KD, Misra BP \& Katiyar RR (1978). Prey preference of C. septempunctata L. (Coleoptera: Coccinellidae). Ind J of Agri Sci 48(2): 84-86.

39. Sinha TB, Pandey RK, Singh R, Tripathi CPM \& Kumar A (1982). The functional response of $C$. septumpunctata Linn., a Coccinellid predator of mustard aphid, L. erysimi Kalt. Entomol 7: 7-10.
40. Takahashi K (1993). Daily behavior of adult $C$. septempunctata brucki (Coleoptera, Coccinellidae). Jap J of Entomol 61(4): 839-845.

41. Agarwala BK \& Ghosh AK (1988). Prey records of aphidophagous Coccinellidae in India. A review and bibliography. Trop Pest Manag 34(1): 1-14.

42. Pandey AK. \& Khan MA (2002). Feeding potential of Coccinella septempunctata Linn. (Coccinellidae: Coleoptera) on mustard aphid, Myzus persicae Sulzer. Pestol 26(1): 26-29.

43. Nath, DK. \& Sen B (1976). Some observations on aphidophagous coccinellid beetles in mustard cultivations. Sci and Cult 42(5): 288290.

44. Sureja BV (1991). Bio-ecology and utilization of predatory Coccinellids for the control of aphids. Ph. D. Thesis R.A.U, Bikaner campus: Udaipur. 